\title{
External morphological stages and protein variations along with the embryonic development of the longarm river prawn Macrobrachium tenellum (Smith, 1871)
}

\author{
Marcelo U. García-Guerrero $^{1}\left(\mathbb{D}\right.$, Dulce M. Mateos-Guerrero ${ }^{2}$ \\ Juan J. Alpuche-Osorno ${ }^{3}$ (D) R Rodolfo B. De los Santos-Romero 2 \\ ${ }^{1}$ Laboratorio de Acuicultura Experimental, CIIDIR- Oaxaca Instituto Politécnico Nacional \\ Santa Cruz, Xoxocotlán, Oaxaca, México \\ ${ }^{2}$ Tecnológico Nacional de México - Instituto Tecnológico del Valle de Oaxaca \\ Santa Cruz, Xoxocotlán, Oaxaca, México \\ ${ }^{3}$ Centro de Investigación Facultad de Medicina UNAM-UABJO, Facultad de Medicina y Cirugía \\ Universidad Autónoma Benito Juárez de Oaxaca, Oaxaca de Juárez, Oaxaca, México \\ Corresponding author: Rodolfo Benigno de los Santos-Romero (rdelossr@hotmail.com)
}

\begin{abstract}
A good understanding of a given species' embryology is important to settle the larval rearing bases when juveniles are required for culture purposes or conservation programs. Changes in embryonic morphology, protein concentration, and protein type occurring in prawn eggs were analyzed in the present work. Berried females of Macrobrachium tenellum were collected in the Colotepec River, Oaxaca, Mexico. The eggs were taken from the ovigerous mass and embryonic stages classified by their color. Morphological changes in the embryos allowed identifying six embryonic stages based on color, egg size, and morphological features. Determinations of the protein extract were executed in SDS-PAGE (electrophoresis in polyacrylamide gels) and, subsequently, proteomic analyses were also performed. Protein bands along embryonic development and their molecular weights are presented and commented.
\end{abstract}

Keywords: Palaemonidae; Macrobrachium tenellum; embryology; eggs; electrophoresis; ontogeny; proteomics

\section{INTRODUCTION}

In the last 40 years, a series of studies have been conducted to understand the basic biology of some Latin American Macrobrachium prawns (GarcíaGuerrero et al. 2013) but not as much as those reported for some Asian species such as Macrobrachium rosenbergii (De Man, 1879). Along the Pacific coast of Mexico, one of the most common species is Macrobrachium tenellum (Smith, 1871), distributed from Mexico to Peru, mostly in riverine basins connected to the sea. In Latin America, the first studies with Macrobrachium prawns were conducted with this species by Román-Contreras (1979), Guzmán et al. (1981), and Guzmán (1987), dealing with ecological and reproductive aspects, research that continues until now. However, information concerning the early stages of their life cycle is almost unknown, and few works have contributed to understanding their embryonic and larval development (García-Guerrero 2010, GarcíaGuerrero et al. 2013). A good understanding of embryology is important to set the basis for larval rearing since juveniles are required for culture or conservation programs. Vega-Villasante et al. (2012) mention that one of the main problems during the embryonic development of $M$. tenellum is caused by poor water quality, which affects development, hatching, and survival. Some previous works suggest that the amount and kind of lipids and proteins as egg components determine yolk quality and egg quality (García-Guerrero 2009, 2010, García-Guerrero \& Hernández-Sandoval 2012, Soundarapandian et al. 2013). These latter works suggest a close relationship between the egg quality and the amount of proteins, lipids, and carbohydrates stored as nutrients in Macrobrachium eggs. 
It is important to consider that females carry the eggs attached to the pleopods until hatching. During this time, the embryo uses lipoprotein-rich yolk components as fuel and as a source for tissue synthesis (Luo et al. 2004, Habashy et al. 2012). Palaemonidae eggs are centrolecithal, covered with a transparent chorion, and a great variation in size among species (Odinetz-Collart \& Rabelo 1996). The egg's size could change along with development, mainly due to water absorption caused by converting the yolk components into living tissue (Vargas-Ceballos et al. 2018). An advantage in the study of embryogenesis is that morphological changes can be identified through the direct observation of eggs because the chorion is transparent (Muller et al. 2003, Habashy et al. 2012, Mejia-Ortiz et al. 2016). In fact, there is a method that allows registering morphological changes based on the quantitative development of embryonic structures, being the ocular lobes the most evident (Beltz et al. 1992). This criterion is called staging (Sandeman \& Sandeman 1991) and daily staging schemes (Nazari et al. 2000, 2003).

However, one of the difficulties for interspecific comparisons is that embryo developmental change can vary in duration among species and temperaturedependent. For example, at $23^{\circ} \mathrm{C}, 10$ days in Palaemonetes argentinus (Nazari et al. 2000); at $25^{\circ} \mathrm{C}$, 14 days in Macrobrachium olfersi (Müller et al. 2003); at $25-26^{\circ} \mathrm{C}, 16$ days in $M$. rosenbergii (Clarke et al. 1990 ); at $26-28^{\circ} \mathrm{C}, 17$ days in M. tenellum (EspinosaChaurand et al. 2011); and at $24^{\circ} \mathrm{C}, 18$ days in $M$. americanum (Yamasaki-Granados et al. 2013).

Although embryogenesis of crustaceans has a common pattern, there are specific details, and only previous works describing in detail the embryonic morphology of Macrobrachium species are somewhat comparable (Mejia-Ortiz et al. 2016). M. rosenbergii is the most studied species in all fields, including embryology (Caceci et al. 1996). For American species, examples are the works with M. olfersii, M. acanthurus, and M. americanum (Müller et al. 2004, 2007, GarcíaGuerrero \& Hendrickx 2009). There are very few works studying $M$. tenellum eggs. Hernández-Abad et al. (2018), working with Macrobrachium acanthurus, studied the effects of different dietary lipid levels on the growth, egg production, and egg quality, observing that a lipid inclusion between 15 and $17.5 \%$ seems to be appropriate for maturation and egg production. However, studies considering external morphology or biochemical changes inside the eggs are not available, as previously stated by Jaramillo et al. (2017), and such information is a useful tool in the understanding of environmental and physiological requirements associated with the viability of the eggs along with development as a part of the reproduction process. The present work aims to provide basic knowledge in the variation of the amount and kind of proteins occurring during embryonic development, supported by details on the embryo's external morphological changes.

\section{MATERIALS AND METHODS}

Ten adult males and 40 females Macrobrachium tenellum prawns were collected in the Colotepec River $\left(15^{\circ} 48^{\prime} 19^{\prime \prime} \mathrm{N}, 97^{\circ} 01^{\prime} 09^{\prime \prime} \mathrm{W}\right)$ Oaxaca, Mexico. Prawns were caught with hand nets along with the vegetation of the river bank. They were transported in $250-\mathrm{L}$ cylindrical containers filled with water from the river and with continuous aeration. Once in the laboratory (Laboratorio de Acuacultura, CIIDIR-Oaxaca-IPN), all prawns were acclimated for $24 \mathrm{~h}$. After that, two males and 10 females were maintained in 1000-L tanks with fresh water at $28^{\circ} \mathrm{C}, 5.0 \mathrm{mg} \mathrm{O}_{2} \mathrm{~L}^{-1}, 12: 12$ light:dark, and fed with $35 \%$ protein shrimp pellet (Camaronina ${ }^{\circledR}$ Ciudad Obregon, Mexico). None of the females was berried initially; they were maintained in freshwater since salty water is proper for larval development only in Macrobrachium prawns. Once they were fed and placed with males, females started to molt and became berried. Over a week, several females lay eggs, approximately four or five per week, but this was irregular. Only some days, a berried female was obtained. After three weeks, a total of 23 berried females were utilized for the study. When a female was detected as berried, it was separated and placed with the other females in the same condition. Those females were transported to the Biochemistry Laboratory of the UNAM-UABJO School of Medicine to work with the eggs in sterile conditions. Embryonic stages from egg masses were observed and classified.

The eggs were taken from the ovigerous masses and rinsed with distilled water before removing them with dissection pincers for analysis. Embryological stages were classified according to color in agreement with Guzmán et al. (1981). Then, half of the eggs were rinsed again with distilled water $(2 \mathrm{x})$ and kept in 1.5 $\mathrm{mL}$ microtubes filled with a PBS solution $1 \mathrm{x}(\mathrm{NaCl}$, $\mathrm{kH} 2 \mathrm{PO} 4, \mathrm{KCl}, \mathrm{pH} 7.2$ ) and stored at $-80^{\circ} \mathrm{C}$ until their analysis. The other half was preserved in $4 \% \mathrm{PFH}$ (4\% paraformaldehyde in PBS 1x) for three hours in dark conditions. They were then rinsed with a saline solution $(0.85 \% \mathrm{NaCl})$ and stored at $4^{\circ} \mathrm{C}$ until analysis.

Morphological changes in the embryos were observed by placing the eggs under an optical microscope (Zeiss-PrimoStar, USA) at 4 and 10x. Pictures were taken with a digital camera (AxiocamERC- 5s, Germany) and the ZEN program (Zeiss, Germany) using the manual extended focus and 
measurement annotation module. Distinctive features at every stage of development were registered and analyzed both in life and from pictures.

The biochemical analysis was executed on the frozen eggs in PBS $1 \mathrm{x}\left(-80^{\circ} \mathrm{C}\right)$. The homogenate was obtained by chopping the eggs with a mortar (sterilized and cooled to $-80^{\circ} \mathrm{C}$ ), adding $300 \mu \mathrm{L}$ of RIPA buffer with protease inhibitors (Sigma Chemicals, cat. S8220) at $-4^{\circ} \mathrm{C}$. This homogenate was then centrifuged at $12,000 \mathrm{rpm}$ for $10 \mathrm{~min}$ at $0^{\circ} \mathrm{C}(2 \mathrm{x})$, and the supernatant separated and frozen at $-80^{\circ} \mathrm{C}$ until use. The quantification of proteins in the supernatant was measured with the BCA micro method (Bicincolinic Acid, Pierce, USA) using bovine albumin serum as standard (Dort et al. 2016). A $25 \mu \mathrm{L}$ sample was placed in triplicate in a microplate, and $200 \mu \mathrm{L}$ of BCA reagent was added to each. Then, the plate was incubated at $37^{\circ} \mathrm{C}$ for $30 \mathrm{~min}$, and the absorbance was recorded at $570 \mathrm{~nm}$. Total protein values were calculated in $\mathrm{mg} \mathrm{mL}^{-1}$. Protein extract determinations were performed according to Mexía-Salazar et al. (2008). SDS-PAGE (electrophoresis in polyacrylamide gels under reducing and denaturing conditions) using a 5\% concentrator gel (acrylamide/BIS, water, 0.5 M Tris, pH 6.8, 10\% SDS, ammonium persulfate, TEMED) and another $12.5 \%$ separator (acrylamide/BIS, water, 1.5 M Tris, $\mathrm{pH} 8.8$, $10 \%$ SDS, ammonium persulfate, TEMED). Samples were diluted 1:1 with Laemmli $2 x$ buffer to obtain a concentration of $50 \mu \mathrm{g} \mathrm{mL}^{-1}$ of total protein. Then, the samples were incubated at $98^{\circ} \mathrm{C}$ for $10 \mathrm{~min}$, and electrophoresis was run at $100 \mathrm{~V}$. After electrophoresis, the gel was stained with Coomassie blue (BioRad, USA) and after $12 \mathrm{~h}$, destained with a decolorizing solution (10\% acetic acid, 50\% methanol, 50\% distilled water).

Proteomic analyses were executed in agreement with Hernández-Pérez et al. (2019) that includes only stage E eggs. Protein extracts were lyophilized and sent for analysis to Creative Proteomics (Shirley, NY, USA). The analysis performed was as follows, using the Nano LC-MS/ MS platform: $5 \mathrm{mg}$ of dissolved protein was placed in $200 \mu \mathrm{L}$ of $50 \mathrm{mM}$ ammonium bicarbonate. The solution was transferred to Microcon YM-10 (Millipore) devices. The device was centrifuged at $12,000 \mathrm{rpm}$ at $4^{\circ} \mathrm{C}$ for $10 \mathrm{~min}$. Subsequently, $200 \mu \mathrm{L}$ of $50 \mathrm{mM}$ ammonium bicarbonate was added to the concentrate and centrifuged again and reduced to $10 \mathrm{mM}$ DTT at $56^{\circ} \mathrm{C}$ for $1 \mathrm{~h}$ and alkalized with $20 \mathrm{mM}$ IAA at ambient temperature in the dark for $1 \mathrm{~h}$. Then, the solution was centrifuged at $12,000 \mathrm{rpm} \mathrm{g}$ at $4^{\circ} \mathrm{C}$ for $10 \mathrm{~min}$ and rinsed with $50 \mathrm{mM}$ ammonium bicarbonate. One hundred microliters of $50 \mathrm{mM}$ ammonium bicarbonate and free trypsin were added to the protein solution at a
1:50 ratio, and the solution was incubated at $37^{\circ} \mathrm{C}$ for $12 \mathrm{~h}$. Finally, the solution was centrifuged at 12,000 $\mathrm{rpm}$ at $4^{\circ} \mathrm{C}$ for $10 \mathrm{~min}$. Ten hundred microliters of 50 $\mathrm{mM}$ ammonium bicarbonate were added to the solution and centrifuged again. The extracted peptides were lyophilized, and peptides were resuspended in 2 to 20 $\mu \mathrm{L}$ of $0.1 \%$ formic acid before LC-MS/MS analysis. Once the analysis was finished, a search on the Macrobrachium proteins database (Crustacea, Decapoda) was performed using Proteome Discoverer 2.0 (ThermoFisher Scientific). The parameters were established as follows: the protein modifications were carbamidomethylation (C) (fixed), oxidation (M) (variable). The enzymatic specificity was adjusted to trypsin; the maximum fractures lost were fixed at 2; the precursor ion masses' tolerance was set at $10 \mathrm{ppm}$, and the MS/MS tolerance was 0.6 Da.

From these analyses, only peptides identified with high confidence were selected for protein identification. Data from biochemical samples were analyzed in triplicate using the Minitab Statistical Software, version 17.

\section{RESULTS}

Six different embryonic developmental stages were recognized $(n=50)$. Figure 1 depicts the morphological changes per stage observed in the embryos, emphasizing the appearance of new structures for each stage. Sizes and color changes in the eggs $(n=50)$, ranging from 481 to $692 \mu \mathrm{m}$ length and 4.38 to $469 \mu \mathrm{m}$ width are shown (Table 1). A continuous increase in volume along developmental time is observed.

Concerning biochemical changes, the concentration of soluble protein varied depending on the stage $\left(\mathrm{R}^{2}=\right.$ 0.95): new eggs: $5.04 \mathrm{mg} \mathrm{mL}^{-1}$; eggs in stage $A$ and stage B with 24.35 and $4.23 \mathrm{mg} \mathrm{mL}^{-1}$, respectively; eggs in stage $\mathrm{C}$ with $13.3 \mathrm{mg} \mathrm{mL} \mathrm{O}^{-1}$; and eggs in stages $\mathrm{D}$ and $\mathrm{E}$ with 0.75 and $1.17 \mathrm{mg} \mathrm{mL}^{-1}$, respectively. The molecular weight of the proteins found in every stage is shown (Fig. 2). Protein bands at 250-kDa molecular weight were observed in all stages, but with overexpression only in stage E. Proteins with a weight of $20,250,50,37,25 \mathrm{kDa}$ were present in all stages. Protein bands with medium and small molecular weight varied depending on the stage, and that was the case of new eggs, where only protein bands with a molecular weight of 150 and $100 \mathrm{kDa}$ were observed. In stage C, just the protein band of $2 \mathrm{kDa}$ was found. In stages A and $\mathrm{D}$, only the $10 \mathrm{kDa}$ protein band was present. In the $D$ and $E$ stages, protein bands were current with 42, 41, 39,27 , and $23 \mathrm{kDa}$. Also, eight proteins with at least 1000 amino acids were identified in stage D eggs, mostly related to vitellogenin (Q95P34) and vitellogenin 

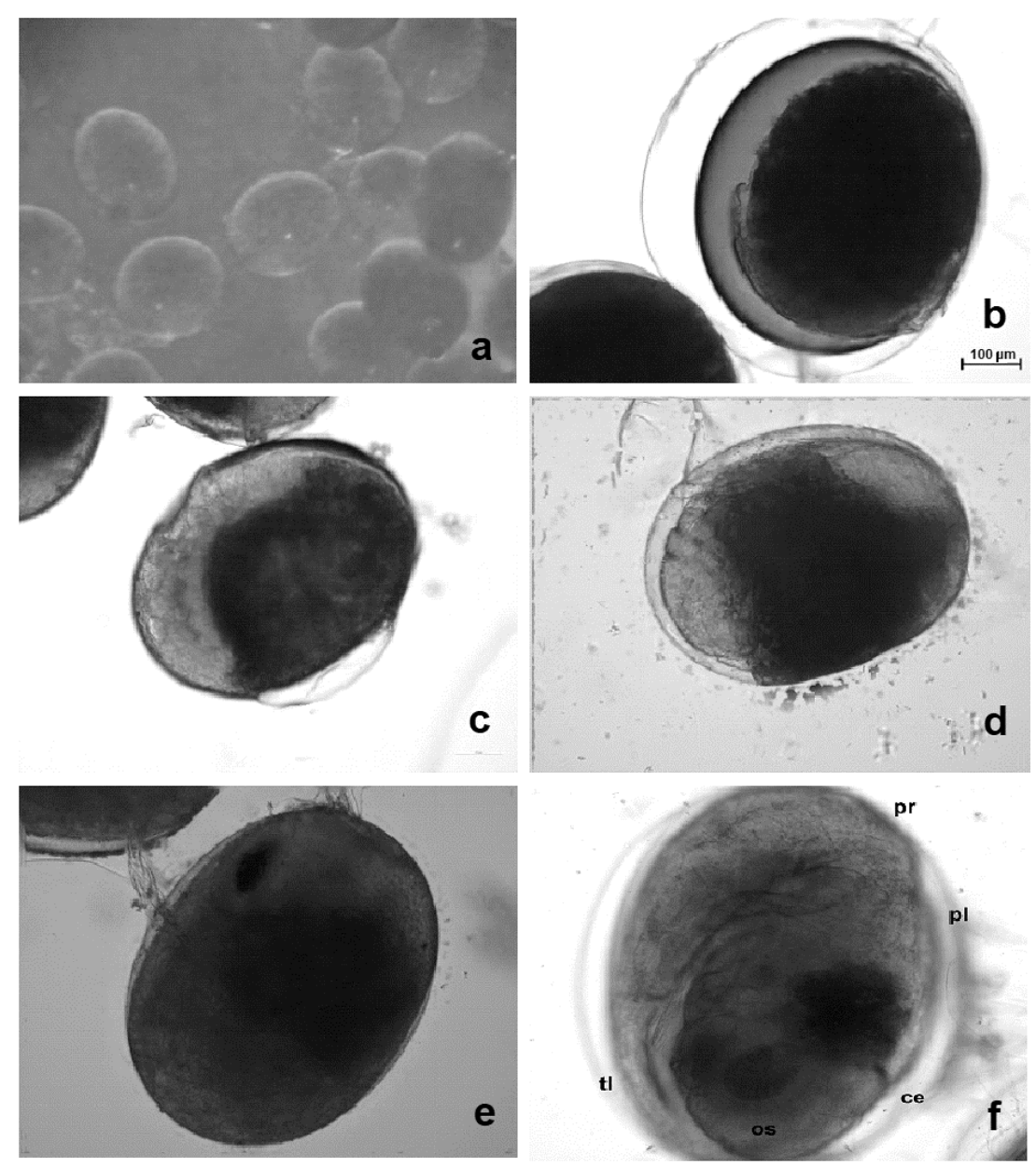

Figure 1. Morphological changes in the embryos of Macrobrachium tenellum along with embryonic development. os: ocular spot, ce: cephalon, pr: pereion, pl: pleon, tl: telson, v: yolk. a) New eggs: spherical, no cells or structures are observed, translucent yolk, b) stage A: the blastomeres are observed, and the yolk is denser and more homogeneous, c) stage B: the cephalic structures and the tagmas that correspond to the prymordia of the pereion and the pleon appears, d) stage C: the embryo has a "C" shape. It is located at one side of the egg, and the pleon begins to split into segments. There is pigmentation of the ocular spot, and yolk occupies more than half the egg, e) stage D: the oval ocular spot with reddish pigmentation is forming, and the segmentation of the pleon is more evident. The telson is starting, and the yolk occupies less than half the egg, f) stage E: the embryo occupies most of the egg, eyes totally pigmented, pereion, pleon, telson, and uropods welldefined. The embryo is almost fully developed.

(A0A0E3JBN6) with a molecular weight of 285 and $286 \mathrm{kDa}$, respectively (Table 2 ).

\section{DISCUSSION}

The embryonic development encountered in the present work is equivalent to that proposed by Muller et al. (2004) for Macrobrachium potiuna and M. olfersi. Four stages have been recognized: new eggs, prenaupliar, naupliar, and postnaupliar. It is very similar to the five stages identified by Graziani et al. (1993) for $M$. carcinus or the nine stages proposed by GarcíaGuerrero \& Hendrickx (2009). All these different species might have the same developmental process, differing only in developmental time and the description criteria. Different approaches or criteria describe a part of a life cycle comparable in all embryonic stages of other crustaceans and almost equal in any Macrobrachium species. From the observations made in the eggs of the present work and aimed at giving a synthesized classification, at least three development stages can be proposed: pre-embryonic stage (stages A and B), during which segmentation and gastrulation occur. Then, the embryonic stage equivalent to stages $\mathrm{C}$ and $\mathrm{D}$ implies the development of primary cephalic structures. Stage E, which is the most extended and complex, begins with developing the ocular and abdominal structures and agrees with the 
Table 1. Changes in size and color of Macrobrachium tenellum eggs along with embryonic development.

\begin{tabular}{lcccc}
\hline \multirow{2}{*}{ Stage } & \multicolumn{2}{c}{ Egg size } & Color & $\begin{array}{c}\text { Volume } \\
\left(\mathrm{mm}^{3}\right)\end{array}$ \\
\cline { 2 - 3 } & $\begin{array}{c}\text { Long } \\
(\mu \mathrm{m})\end{array}$ & $\begin{array}{c}\text { Width } \\
(\mu \mathrm{m})\end{array}$ & & \\
\hline New eggs & $561 \pm 26$ & $454 \pm 16$ & brown yellow & 0.274 \\
A & $491 \pm 56$ & $456 \pm 26$ & green & 0.267 \\
B & $544 \pm 35$ & $444 \pm 13$ & green- yellow & 0.255 \\
C & $571 \pm 20$ & $438 \pm 6$ & yellow & 0.258 \\
D & $654 \pm 58$ & $442 \pm 69$ & brown & 0.335 \\
E & $682 \pm 32$ & $469 \pm 30$ & brown & 0.332 \\
\hline
\end{tabular}

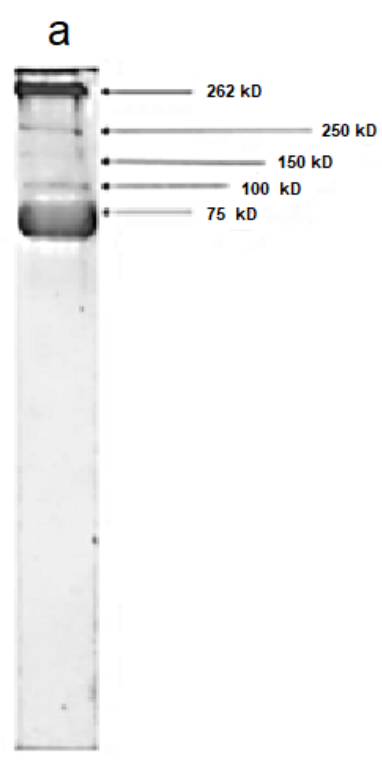

b

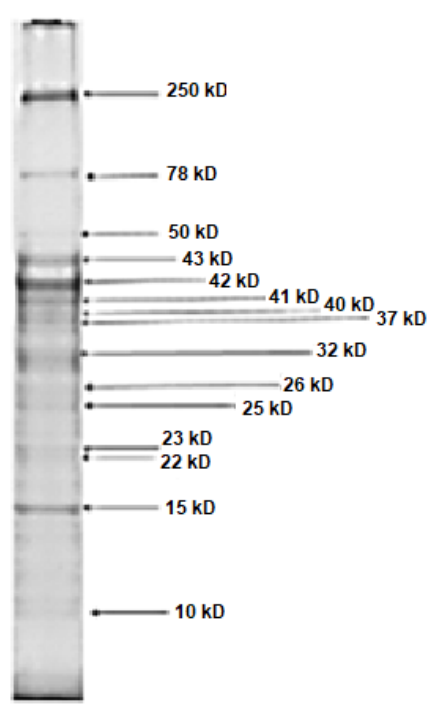

e

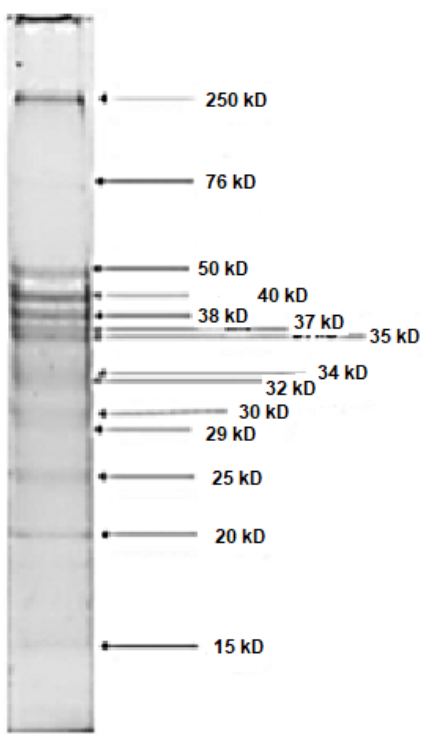

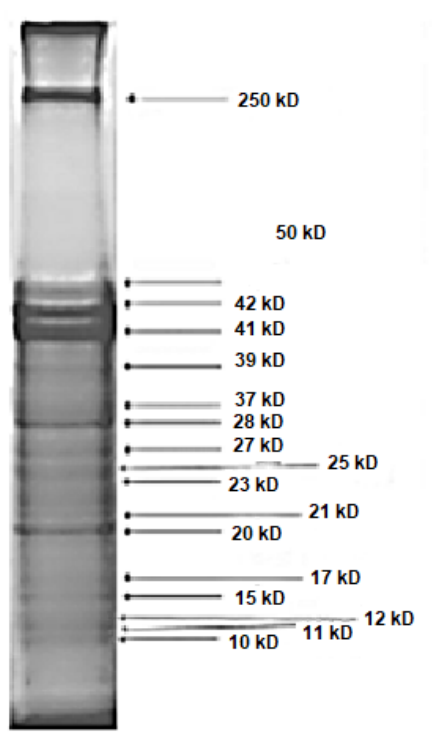

C

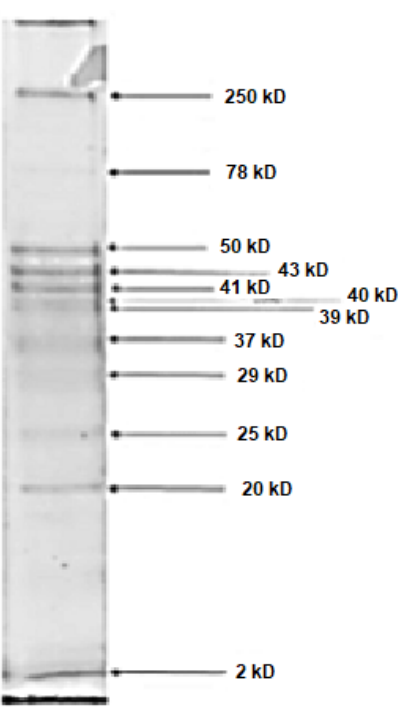

f

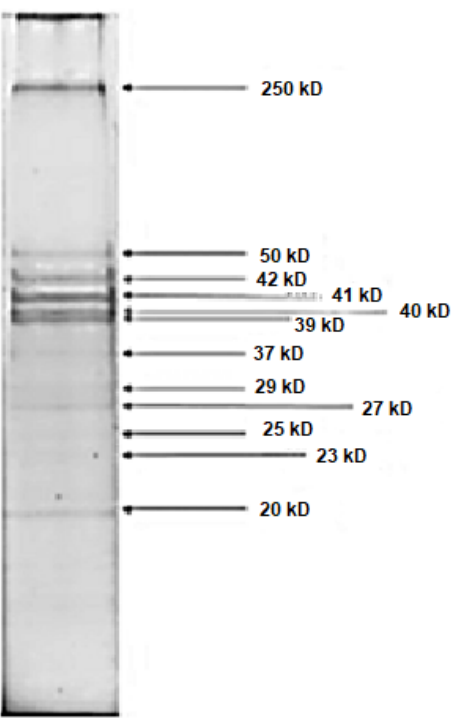

Figure 1. According to the stage of embryonic development and molecular weights, protein bands along with Macrobrachium tenellum embryonic development. a) New hatch, b) eggs in stage A, c) eggs in stage B, d) eggs in stage C, e) eggs in stage D, f) eggs in stage E. 
Table 2. Main proteins identified (LC-MS / MS) in eggs of Macrobrachium tenellum, ordered by quantity (protocol emPAI). Accession is the identifier of the UniProt database; the name of the identified protein is shown. The species name is in which the protein was originally reported; AAs\#: number of amino acids; MW: molecular weight; and calc. pI: calculated isoelectric point. emPAI and Score Sequest HT are values derived from algorithms for relative quantization and perfect match control of mass spectra.

\begin{tabular}{lllllllc}
\hline Accession & \multicolumn{1}{c}{ Description } & \multicolumn{1}{c}{ Species } & AAs\# & MW [kDa] & calc. pI & emPAI & Score Sequest HT \\
\hline Q95P34 & Vitellogenin & Macrobrachium rosenbergii & 2537 & 285.48 & 8.95 & 89.852 & 14270.06713 \\
A0A0E3JBN6 & Vitellogenin & Macrobrachium nipponense & 2536 & 286.626 & 8.92 & 76.668 & 14829.9339 \\
A0A0E3JBQ2 & Vitellogenin receptor & Macrobrachium nipponense & 1902 & 209.508 & 5.62 & 0.022 & 4.322479963 \\
G8Z9Y7 & Vitellogenin receptor & Macrobrachium rosenbergii & 1889 & 208.137 & 5.57 & 0.021 & 4.057481885 \\
\hline
\end{tabular}

pre-naupliar, naupliar, and post-naupliar stages, as defined by Müller et al. (2003) and García-Guerrero \& Hendrickx (2009).

There are different criteria for characterizing embryonic development stages (Nazari et al. 2000), but the development seems always to follow a common pattern in all Palaemonid prawns. However, its duration and success depend on several external factors. For $M$. tenellum, the time from new eggs to hatching at $27^{\circ} \mathrm{C}$ is $17 \pm 1 \mathrm{~d}$ (Espinosa-Chaurand et al. 2011), less if compared with $M$. carcinus and $M$. americanum, in which the development time is $20 \pm 1 \mathrm{~d}$ at 24 and $25^{\circ} \mathrm{C}$, respectively (Graziani et al. 1993, García-Guerrero \& Hendrickx 2009, García-Guerrero et al. 2013). Also, Müller et al. (2003) worked with some of the smaller species of the genus (M. olfersi), in which embryonic development may last $14 \pm 1 \mathrm{~d}$ at $25^{\circ} \mathrm{C}$ and have the shortest period recorded. It is also important to consider that incubation time could be species-dependent but is influenced by water physico-chemistry, being temperature the main factor (Habashy et al. 2012). The temperature might make the developmental time of embryonic structures slower or faster, making the classification into stages, based on time, a non-reliable criterion, leading to arbitrary stages. To avoid this problem, the present results classified the development into percentages, as initially proposed by Sandman \& Sandman (1991) and later by Tinikul et al. (2016): stage $\mathrm{A}=20 \%, \mathrm{~B}=40 \%, \mathrm{C}=60 \%, \mathrm{D}=80 \%$ and $\mathrm{E}=100 \%$. This criterion allows a comprehensible distribution of the stages and permits the comparison of embryogenesis among species in a more accurate way (Odinetz-Collart \& Rabelo 1996).

In Macrobrachium species, particularly M. tenellum and $M$. americanum, all structures appear and grow in a similar sequence, following matching patterns (García-Guerrero et al. 2015). Morphological features of $M$. tenellum observed in the present study are equivalent to those described for other Macrobrachium prawns, such as M. olfersii (Müller et al. 2003), $M$. acanthurus (Müller et al. 2007), and M. americanum
(García-Guerrero \& Hendrickx 2009). Indeed, Espinosa-Chaurand et al. (2011) indicate that $M$. tenellum in its early stages of development begins with a holoblastic segmentation at approximately $4 \mathrm{~h}$ after fertilization that ends at $32 \mathrm{~h}$. It seems to be equivalent to stage A of the present study (Fig. 1). The first structures of the embryo begin to differentiate starting on the third day and, on the fourth day, the appendices are formed, equivalent to stage B. The optical lobes develop during the seventh day, the pigment of the eyes at the end of the eighth day, and on the 10th day, the chromatophores appear, and the heart is formed and beating, which is equivalent in this work to stages $\mathrm{C}$ and $\mathrm{D}$, respectively. The embryo is well-formed on the $12^{\text {th }}$ day, similarly to those obtained in the observation of $\mathrm{E}$ stage eggs of the present work. In M. americanum, this method even allows observing major embryonic structures' development without cytological techniques (García-Guerrero \& Hendrickx 2009). This technique seems to be proper because the external structures are few and well-differentiated. Most of them are easily observed through the chorion. A partial match with other Decapoda such as Palaemonetes argentinus (Müller et al. 2003) is also observed. These authors mention that this method is precise and easy to apply for decapod embryology, and the present work confirms that embryonic development depicts a similar matching pattern. The staging method based on percentages has been useful to characterize the embryonic development of $M$. americanum (GarcíaGuerrero \& Hendrickx 2009). As in the present work, this criterion was also useful to describe and divide the embryonic development in percentages based on morphological changes observed in the egg. It is clear that the method could be useful for any Decapoda with lecithotropic centrolecithal eggs such as Caridea and Astacidea (Sandeman \& Sandeman 1991, GarcíaGuerrero et al. 2003), Brachyura (García-Guerrero \& Hendrickx 2004), and Anomura (García-Guerrero \& Hendrickx 2006).

The morphogenesis of the prawn eggs registered in the present work (Table 1) agrees with Müller et al. 
(2004), establishing that an egg increases along with embryonic development. $M$. tenellum eggs are smaller in comparison with other cogeneric species. For example, M. amazonicum (Meireles et al. 2013), $M$. carcinus (Graziani et al. 1993), or even M. rosenbergii (García-Ulloa et al. 2004) are reported to have larger eggs. However, differences in size among the same genus species are probably due to variations in the total amount of water and yolk inside the egg, which can vary not only among species but also among the same species' eggs. Many factors, including female fitness and feeding during maturation and female size, the embryonic stage, or water physico-chemistry, produce a subtle effect on egg size (García-Guerrero \& Hernández-Sandoval 2012). From these results and previous works, it is clear that egg size is related to the species' reproductive strategy and not to the species' average or maximum size.

On the other hand, many previous works with Macrobrachium prawns that proteins in prawn eggs are the main source for tissue synthesis and an additional energy production source and development. GarcíaGuerrero (2009) and García-Guerrero \& HernándezSandoval (2012) state that proteins are regularly the most abundant component in the eggs, as reported for $M$. americanum and M. occidentale. From these works, it has been inferred that proteins lower their concentration significantly along with the development. However, as observed in the present work, soluble proteins increase later and continue until ending egg development. This phenomenon occurred with differences among stages; from the initial stage A to B, there was a drastic decrease in total proteins' concentration from 24.35 to $4.23 \mathrm{mg} \mathrm{mL}^{-1}$. It seems that this is due to an intensive tissue synthesis during gastrulation. Instead of what occurs in further stages $C$, $\mathrm{D}$, and $\mathrm{E}$, where an increase in the total concentration of protein occurred, another decrease is observed from 13.3 to 0.75 and $1.17 \mathrm{mg} \mathrm{mL}^{-1}$, respectively. This trend is similar to that observed by Dinakaran et al. (2013) for Macrobrachium idella idella, in which the concentration of dissolved protein in the egg gradually decreased from stage I $(69.32 \%)$ to stage IV $(54.56 \%)$; these authors established that in zoea I stage the concentration of total protein decreases as hatching approaches, reaching $52.42 \%$.

Morphological and size changes come with modifications in the concentration of biochemical composition. Proteins continuously change in type and amount in the egg depending on stage. The molecular protein weight can be subtracted from the protein band's migration distance to observe such variations, in agreement with Maldonado-Alconada \& Jorrin-Novo (2011). It is observed that depending on the develop- mental stage, proteins vary in molecular weight, but there are some bands (Fig. 2) that are equivalent in their $\mathrm{kDa}$ for different stages of development. Hence, their presence is continuous along with the development. It seems that it is the same protein at different stages and with varying expression levels. The same protein kind could be required along with the whole embryonic development for other tasks. In M. tenellum, all samples of embryonic stages had protein bands with a molecular weight of $250 \mathrm{kDa}$, highlighted in Figure 2, whereas in other species, such as Macrobrachium borelli, the most abundant proteins are expressed in bands at 94 and 112 $\mathrm{kDa}$. A possible explanation could be the presence of many high molecular weight proteins that cause DNA and protein overexpression (García et al. 2006).

Proteins are regularly the major constituent in crustacean eggs since they are essential for tissue synthesis and energy source fuel (García-Guerrero et al. 2003, Luo et al. 2004). Those previous works also recognized that morphological changes occurring in the eggs at different stages are mainly due to continuous protein synthesis and degradation, which constantly produce variations in egg biochemical composition (Habashy et al. 2012). Proteins are essential for most metabolic functions (Qiao et al. 2017). Their exact function in M. tenellum has not been determined yet; they are likely used for species' same functions. Jaramillo et al. (2017), working with $M$. olfersii, indicate that the analysis of protein expression with genes allows establishing the link of the physiological mechanisms at the molecular level, occurring along with the ontogenetic development of prawns.

Also, protein types reported in this work are similar to those described for the larval and post-larval stages of M. olfersii and M. rosenbergii (Barman et al. 2012, Priyadarshi et al. 2015, Jaramillo et al. 2017). Those works suggest that vitellogenin (vg) had the highest gene expression levels in protein isolated from eggs. Other studies indicate that it is also possible to find similarities among proteins, such as glyceraldehyde-3phosphate dehydrogenase (GAPDH), ribosomal protein L8 (RpL8), ribosomal protein L18 (RpL18), $\beta$ actin $(\beta$-act), and elongation factor $-1 \alpha(\mathrm{EF}-1 \alpha)$. Still, these were not quantified in the present work, so comparisons cannot be offered. From those proteins, GAPDH is the most common after vitellin-type proteins. Vitellin-originated proteins have the highest sequence of peptides (Table 2) because they are synthesized in the ovary before and during egg formation and are channeled to the eggs as a lipid carrier (García et al. 2008). For example, Lafontaine et al. (2017) stated that vg is abundant in immature $M$. rosenbergii females. The same occurs in other Palaemonidae, such as Palaemon elegans (Sanders et 
al. 2005, Bai et al. 2016). The latter authors support that $\mathrm{vg}$ is the extra-ovarian precursor of yolk proteins or vitelline, which provides nutrients and energy and the whole development (Matozzo et al. 2008). Regarding $M$. tenellum, it was observed that variations in the amount of proteins, such as vitellin, seem to be due to changes in the total concentration of soluble proteins from stage to stage, which is a consequence of embryonic developmental changes.

This work helps to describe that embryogenesis in crustaceans exhibits a common pattern in both morphological changes and protein profile and development. Structures forming inside the egg are quite similar among species, whereas subtle differences in the genetic expression of proteins and development are found in close species. Those subtle differences among species at different stages of embryonic development can be tracked or determined in the eggs, explaining, perhaps, slight differences in requirements. A better understanding of the use of vg-originated proteins along the embryonic development of crustacean eggs could be reached with specific studies, at the molecular level, including comparisons of this process among species. Jaramillo et al. (2016) suggested that molecular sequences from Macrobrachium prawn eggs can help to understand differences in developmental models among close species with a biomolecular approach.

\section{ACKNOWLEDGMENTS}

RSR thanks Tecnológico Nacional de México and Instituto Tecnológico del Valle de Oaxaca. MGG thanks the Sistema Nacional de Investigadores/Consejo Nacional de Ciencia y Tecnología (SNI/CONACyT), EDI program from the Instituto Politécnico Nacional and the Comisión de Operación y Fomento de Actividades Académicas SIBE Program. JAO wishes to thank CONACYT and FMyC-UABJO for their support.

\section{REFERENCES}

Bai, H., Qiao, H., Li, F., Fu, H., Jiang, S., Zhang, W., Yan, Y., et al. 2016. Molecular and functional characterization of the yolkgenin receptor in oriental river prawn Macrobrachium nipponense. Comparative Biochemistry and Physiology - Part A: Molecular \& Integrative Physiology, 194: 45-55.

Barman, H.K., Patra, S.K., Das, V., Mohapatra, S.D., Jayasankar, P., Mohapatra, C., et al. 2012. Identification and characterization of differentially expressed transcripts in the gills of freshwater prawn
(Macrobrachium rosenbergii) under salt stress. Scientific World Journal, 2012: 1-11.

Beltz, B.S., Helluy, S.M., Ruchhoeft, M.L. \& Gammill, L.S. 1992. Aspects of the embryology and neural development of the American lobster. Journal of Experimental Zoology, 261: 288-297.

Caceci, T., Carlson, C., Toth, T. \& Smith, S. 1996. In vitro embryogenesis of Macrobrachium rosenbergii larvae following in vivo fertilization. Aquaculture, 147: 149165.

Clarke, A., Brown, J.H. \& Holmes, L.J. 1990. The biochemical composition of eggs from Macrobrachium rosenbergii in relation to embryonic development. Comparative Biochemistry and Physiology - Part B: Biochemistry \& Molecular Biology, 96: 505-511.

Dinakaran, G.K., Soundarapandian, P. \& Varadharajan, D. 2013. Embryonic development of the Palaemonid prawn Macrobrachium idella idella (Hilgendorf, 1898). Cell and Developmental Biology, 2: 111.

Dort, J., Leblanc, N., Bryl, P., Fortin, M.G., Carbonneau, M.E., Lavigne, C. \& Jacques, H. 2016. Shrimp protein hydrolysate modulates the timing of proinflammatory macrophages in bupivacaine-injured skeletal muscles in rats. BioMed Research International, 2016: 5214561. doi: 10.1155/2016/5214561

Espinosa-Chaurand, L.D., Vargas-Ceballos, M., GuzmánArroyo, M., Nolasco-Soria, H., Carrillo-Farnés, O., Chong-Carrillo, O. \& Vega-Villasante, F. 2011. Biología y cultivo de Macrobrachium tenellum: estado del arte. Hidrobiológica, 21: 99-117.

García-Guerrero, M. 2009. Proximate biochemical variations in eggs of the prawn Macrobrachium americanum (Bate, 1869) during its embryonic development. Aquaculture Research, 40: 575-581.

García-Guerrero, M. 2010. Effect of temperature on consumption rate of main yolk components during the embryo development of the prawn Macrobrachium americanum (Crustacea: Decapoda: Palaemonidae). Journal World Aquaculture Society, 41: 84-92.

García-Guerrero, M. \& Hendrickx, M.E. 2004. Embryology of decapod crustaceans I. Embryonic development of the mangrove crabs Goniopsis pulchra and Aratus pisonii (Decapoda: Brachyura). Journal of Crustacean Biology, 24: 666-672.

García-Guerrero, M. \& Hendrickx, M.E. 2006. Embryology of decapod crustaceans III. Embryonic development of Europanopeus canalensis Abele \& Kim, 1989, and Panopeus chilensis H. Milne Edwards \& Lucas, 1844 (Decapoda, Brachyura, Panopeidae). Belgian Journal of Zoology, 136: 249 -253.

García-Guerrero, M. \& Hendrickx, M. 2009. External description of the embryonic development of the prawn Macrobrachium americanum based on the staging method. Crustaceana, 82: 1413-1422. 
García-Guerrero, M. \& Hernández-Sandoval, P. 2012. Total protein, lipid, carbohydrate, and water changes of eggs through embryonic development of Macrobrachium occidentale Holthuis, 1950 and its relation to morphological changes. Journal of Crustacean Biology, 32: 769-773.

García-Guerrero, M., Hendrickx, M.E. \& Villarreal, H. 2003. Description of the embryonic development of Cherax quadricarinatus von Martens, 1868 (Decapoda, Parastacidae), based on the staging method. Crustaceana, 76: 296-280.

García-Guerrero, M., Becerril-Morales, F., VegaVillasante, F. \& Espinosa-Chaurand, L.D. 2013. Los langostinos del género Macrobrachium con importancia económica y pesquera en América Latina: conocimiento actual, rol ecológico y conservación. Latin American Journal of Aquatic Research, 41: 651675.

García-Guerrero, M., De los Santos-Romero, R., VegaVillasante, F. \& Cortes-Jacinto, E. 2015. Conservation and aquaculture of native freshwater prawns: the case of the cauque river prawn Macrobrachium americanum (Bate, 1868). Latin American Journal of Aquatic Research, 43: 819-827.

García, C.F., Cunningham, M., Garda, H.A. \& Heras, H. 2008. Embryo lipoproteins and yolk lipovitellin consumption during embryogenesis in Macrobrachium borellii (Crustacea: Palaemonidae). Comparative Biochemistry and Physiology - Part B: Biochemistry \& Molecular Biology, 151: 317-322.

García, C.F., Cunningham, M., Soulages, J.L., Garda, H.A. \& Pollero, R. 2006. Structural characterization of the lipovitellin from the shrimp Macrobrachium borellii. Comparative Biochemistry and Physiology Part B: Biochemistry \& Molecular Biology, 145: 365370.

García-Ulloa, M., Rodríguez, H. \& Ogura, T. 2004. Calidad del huevecillo de dos especies de langostino (Palemonidae) del género Macrobrachium ( $M$. rosenbergii, De Man 1879, y M. tenellum, Smith, 1871) variando la dieta de los reproductores: índices morfométricos. Avances en Investigación Agropecuaria, 8: 1-8.

Graziani, C.A., Chunga, K.S. \& De Donato, M. 1993. Comportamiento reproductivo y fertilidad de Macrobrachium carcinus (Decapoda: Palaemonidae) en Venezuela. Revista de Biología Tropical, 41: 657-665.

Guzmán, A.M. 1987. Biología, ecología y pesca del langostino Macrobrachium tenellum (Smith, 1871), en lagunas costeras del estado de Guerrero, México. Tesis de Doctorado, Universidad Nacional Autónoma de México, Ciudad de México.

Guzmán, A.M., Rojas, G.J.L. \& González, G.L.D. 1981. Ciclo anual de maduración y reproducción del "chacal" Macrobrachium tenellum y su relación con factores ambientales en las lagunas costeras de Mitla y Tres Palos, Guerrero, México (Decapoda: Palaemonidae). Anales del Instituto de Ciencias del Mar y Limnología, 9: 67-80.

Habashy, M.M., Sharshar, M.K. \& Hassan, M.S. 2012. Morphological and histological studies on the embryonic development of the freshwater prawn, Macrobrachium rosenbergii (Crustacea, Decapoda). Journal of Basic and Applied Zoology, 65: 157-165.

Hernández-Abad, G., Hernández-Hernández, L. \& Fernández-Araiza, M. 2018. Effects of different dietary lipids concentrations on the egg production and egg quality produced by Macrobrachium acanthurus females. Latin American Journal of Aquatic Research, 46: 518-524.

Hernández-Pérez, A., Zamora-Briseño, J.A., Ruiz-May, E., Pereira-Santana, A., Elizalde-Contreras, J.M., Pozos-González, S., et al. 2019. Proteomic profiling of the white shrimp Litopenaeus vannamei (Boone, 1931) hemocytes infected with white spot syndrome virus reveals the induction of allergy-related proteins. Developmental and Comparative Immunology, 91: 37-49.

Jaramillo, M.L., Ammar, D., Quispe, R.L., Guzman, F., Margis, R., Nazari, E.M. \& Müller, Y.M.R. 2017. Identification and evaluation of reference genes for expression studies by RT-qPCR during embryonic development of the emerging model organism, Macrobrachium olfersii. Gene, 598: 97-106.

Jaramillo, M.L., Guzman, F., Paese, C.L., Margis, R., Nazari, E.M., Ammar, D. \& Müller, Y.M. 2016. Exploring developmental gene toolkit and associated pathways in a potential new model crustacean using transcriptomic analysis. Development Genes and Evolution, 226: 325-337.

Lafontaine, A., Baiwir, D., Joaquim-Justo, C., De Pauw, E., Lemoine, S., Boulangé-Lecomte, C., et al. 2017. Proteomic response of Macrobrachium rosenbergii hepatopancreas exposed to chlordecone: identification of endocrine disruption biomarkers. Ecotoxicology and Environmental Safety, 141: 306-314.

Luo, W., Zhou, Z.L., Zhao, Y.L., Yang, Z.B. \& Zhang, M.F. 2004. Analysis on the contents of protein and amino acids in Cherax quadricarinatus during different embryonic development stages. Journal of East China Normal University, 1: 88-92.

Maldonado-Alconada, A.M. \& Jorrín-Novo, J.V. 2011. Electroforesis desnaturalizante en geles de poliacrilamida. Análisis de proteínas de hojas de Arabidopsis thaliana. Departamento de Bioquímica y Biología Molecular, Campus Universitario de Rabanales, Córdoba.

Matozzo, V., Gagné, F., Marin, M.G., Ricciardi, F. \& Blaise, C. 2008. Yolkgenin as a Mbiomarker of exposure to estrogenic compounds in aquatic inverte- 
brates: a review. Environment International, 34: 531545.

Meireles, A.L., Valenti, W.C. \& Mantelatto, F.L. 2013. Reproductive variability of the Amazon River prawn, Macrobrachium amazonicum (Caridea, Palaemonidae): influence of life cycle on egg production. Latin American Journal of Aquatic Research, 41: 718-731.

Mejia-Ortiz, M.L., Lopez-Mezia, M., Chim, A.C., PereraPech, Y., Crandall, K.A., Frausto-Martinez, O. \& Santander-Botello, L.C. 2016. Freshwater prawns (Palaemonidae: Macrobrachium) with abbreviated larval development in rivers of Mexico: uses, management and conservation opportunities. In: Bucur, D. (Ed.). River basin management. IntechOpen, London, pp. 295-303.

Mexía-Salazar, A.L., Hernández-López, J., BurgosHernández, A., Cortez-Rocha, M.O., Castro-Longoria, R. \& Ezquerra-Brauer, J.M. 2008. Role of fumonisin B1 on the immune system, histopathology, and muscle proteins of white shrimp (Litopenaeus vannamei). Food Chemistry, 110: 471-479.

Müller, Y., Ammar, D. \& Nazari, E. 2004. Embryonic development of four species of palaemonid prawns (Crustacea: Decapoda) prenaupliar, naupliar and postnaupliar periods. Revista Brasileira de Zoología, 21: 27-32.

Müller, Y., Nazari, E. \& Simões-Costa, M. 2003. Embryonic stages of the freshwater prawn Macrobrachium olfersii (Decapoda, Palaemonidae). Journal of Crustacean Biology, 23: 869-875.

Müller, Y., Pacheco, C., Simões-Costa, M.S., Ammar, D. \& Nazari, E. 2007. Morphology and chronology of embryonic development in Macrobrachium acanthurus (Crustacea, Decapoda). Invertebrate Reproduction and Development, 50: 67-74.

Nazari, E., Muller, Y. \& Ammar, D. 2000. Embryonic development of Palaemonets argentines Nobili, 1901 (Decapoda, Palaemonidae), reared in the laboratory. Crustaceana, 73: 143-152.

Nazari, E., Simões-Costa, S., Müller, Y., Ammar, D. \& Días, M. 2003. Comparisons of fecundity, egg size, and egg mass volume of the freshwater prawns Macrobrachium potiuna and Macrobrachium olfersi (Decapoda, Palaemonidae). Journal of Crustacean Biology 23: 862-868.

Odinetz-Collart, O. \& Rabelo, H. 1996. Variation in egg size of the freshwater prawn Macrobrachium amazonicum (Decapoda, Palaemonidae). Journal of Crustacean Biology, 16: 684-688.

Priyadarshi, H., Das, R., Kumar, A.P., Babu-Gireesh, P., Javed, H., Krishna, G., et al. 2015. Characterization and evaluation of selected house-keeping genes for quantitative RT-PCR in Macrobrachium rosenbergii morphotypes. Fishery Technology, 52: 177-183.

Qiao, H., Fu, H., Xiong, Y., Jiang, S., Zhang, W., Shengming-Sun, S., et al. 2017. Molecular insights into reproduction regulation of female Oriental River prawns Macrobrachium nipponense through comparative transcriptomic analysis. Scientific Reports, 7: 12161.

Román-Contreras, R. 1979. Contribución al conocimiento de la biología y ecología de Macrobrachium tenellum (Smith) (Crustacea, Decapoda, Palaemonidae). Anales del Centro de Ciencias del Mar y Limnología, 6: 137160.

Sandeman, R. \& Sandeman, D. 1991. Stages in the development of the embryo of the freshwater crayfish Cherax destructor. Roux's Archives of Developmental Biology, 200: 27-37.

Sanders, M.B., Billinghurst, Z., Depledge, M.H. \& Clare, A.S. 2005. Larval development and vitellin-like protein expression in Palaemon elegans larvae following xeno-estrogen exposure. Integrative and Comparative Biology, 45: 51-60.

Soundarapandian, P., Sudhakar, S., Varadharajan, D. \& Dinakaran, G.K. 2013. Biochemical composition during the embryonic development and freshly hatched zoea of Macrobrachium idae (Heller, 1862). Journal of Earth Science and Climatic Change, 5: $6 \mathrm{pp}$.

Tinikul, Y., Poljaroen, J., Tinikul, R. \& Sobhon, P. 2016. Changes in the levels, expression, and possible roles of serotonin and dopamine during embryonic development in the giant freshwater prawn, Macrobrachium rosenbergii. General and Comparative Endocrinology 225: 71-80.

Vargas-Ceballos, M., López-Uriarte, E., García-Guerrero, M., Wehrtmann, I., Ríos-Jara, E. \& Vega-Villasante, E. 2018. Fecundity, egg volume and reproductive output of Macrobrachium tenellum (Crustacea: Palaemonidae) from the northern coast of Jalisco, Mexico. Latin American Journal of Aquatic Research 46: 502-511.

Vega-Villasante, F., Espinosa-Chaurand, L.D., FloresZepeda, C., Carrillo-Farnés, O. \& Nolasco-Soria, H. 2012. Efecto del nivel proteico de la dieta sobre el desarrollo de juveniles de Macrobrachium tenellum. Revista MVZ Córdoba, 17: 3140-3146.

Yamasaki-Granados, S., García-Guerrero, M., VegaVillasante, F., Castellanos-León, F., Cavalli, R. \& Cortés-Jacinto, E. 2013. Experimental culture of the river prawn Macrobrachium americanum larvae (Bate, 1868), with emphasis on the stocking density effect on survival. Latin American Journal of Aquatic Research, 41: 793-800. 